Received: 27/07/2018

Revision: 10/11/2018

Accepted: $15 / 11 / 2018$

OnlineFirst: 22/11/2018

\title{
Turkish Academics' Foreign Language Academic Literacy: A Needs Analysis Study
}

\section{Gül Durmuşoğlu Köse}

Prof., Anadolu University, Faculty of Education, Turkey, gdurmuso@anadolu.edu.tr

\section{İlknur Yüksel}

Asst. Prof., corresponding author, Eskişehir Osmangazi University, Faculty of Education, Turkey,yukseli@esogu.edu.tr

\section{Yusuf Öztürk}

Dr., Muş Alparslan University, Faculty of Education, Turkey, y.ozturk@alparslan.edu.tr

\section{Musa Tömen}

Res. Asst., Anadolu University, Faculty of Education, Turkey, mtomen@anadolu.edu.tr

\begin{abstract}
For academics, foreign language academic literacy is essential in order to read and analyze academic sources in the foreign language effectively as well as to produce and present their own work in that language. In spite of various studies and trainings on English for academic purposes, it is still questioned why academics and graduate students cannot have the literacy in this area. To address this problem, it is necessary to examine and determine their needs for foreign language academic literacy. Therefore, the present paper reports a large scale needs analysis on the academics and graduate students across different disciplines all over Turkey. Applying quantitative research method, this study adapted a survey model to determine and discuss which academic language skill is the most difficult and what language skill competencies they should improve from their perspective. The results were analyzed in terms of the language skill competencies and the participants' disciplines they studied. The findings indicated that the participants needed most of the competencies questioned in the survey, and their needs were language-skill specific rather than discipline-specific. The participants mostly emphasized academic writing competencies, which supports the assumption in the literature that productive skills are the most difficult skill to improve for learners.
\end{abstract}

Keywords: academic literacy, needs analysis, Turkish academics, graduate students, foreign language

Citation: Durmuşoğlu Köse, G., Yüksel, İ., Öztürk, Y., \& Tömen, M. (2019). Turkish Academics' Foreign Language Academic Literacy: A Needs Analysis Study. International Journal of Instruction, 12(1), 717-736. https://doi.org/10.29333/iji.2019.12146a 


\section{INTRODUCTION}

The globalization of education in English, the lingua franca, has long created a need to provide academic language support to scholars and students, but their competence in this area is still not adequate so as to meet the academic language demands in their disciplines and programs (Read, 2008). Although English language teaching has often been discussed also in the Turkish context, no consensus has been reached to overcome this problem yet. Insufficient academic skills observed in Turkish EFL learners' academic studies denote their need for academic language skills. The literature on English for academic purposes (EAP henceforth) emphasize that especially those who have learnt English as a foreign language have difficulties due to various reasons such as limited exposure to the language, limited number of opportunities in using the language, and insufficient studies in English as an academic language (Savaş, 2009; Hyland, 2009).

With the Bologna process, European institutions have sought for establishing a common higher education framework and thus aimed to eliminate the language barriers of intensive English students in many universities in the countries where native language is not English and to ensure their professional and personal development, enabling them to gain necessary language abilities. Turkey is one of the countries involved in this process and has made radical changes for learners' language development. Despite the steps taken, English language proficiency is one of the burning issues and a kind of burden for Turkish undergraduate and graduate students as well as for academics in Turkey. This was also put forth with British Council and TEPAV's (2013; 2015) comprehensible case study on English Language in the higher education institutions in Turkey as well as the results of national language examinations (e.g. ÜDS, KPDS, YDS) announced and explained by the Turkish Higher Education Council (YÖK, 2014). In these examinations, certain aspects of academic literacy competencies are measured in English, and more structured and cognitive language skills are tested. Even in this limited scope, test-takers have been observed to have great difficulty in these examinations and mostly fail them. Savaş (2009) states that many Turkish students taking foreign language examinations have difficulty in reading comprehension questions and they fail to make inferences they are expected to do. Moreover, of the 298.000 academics, prospective academics and doctors who took the YDS exam in April 2014, 220.000 failed to achieve the threshold score of 50, and the success rate of the exam was announced to be $30 \%$ (YÖK, 2014). These figures indicate that Turkish academics' and students' foreign language academic literacy competencies have not been developed as much as it was targeted.

Due to Turkish academics' limited language abilities and particularly the problems they have in academic reading and writing in English, it is a known fact that they have difficulty in mastering the international literature, publishing in a quality and respectable journal, and presenting their own research to a multilingual audience. Thus, limited foreign language proficiency seems to hinder Turkish academics to take place in international information sharing platforms (Buckingham, 2008; Genç \& Bada, 2010; Yağız \& Yiğiter, 2012). Thus, there is an urgent need to examine Turkish academics' 
foreign language academic literacy covering language skills and suggest the solutions to increase the quantity and quality of international academic products (YÖK, 2014; TEPAV, 2015).

Addressing to this need, different from other studies, which focused on the general English proficiency (e.g. TEPAV, 2015), the present study studied on academic English literacy of Turkish academics and graduate students; encompassing the basic language skills and competencies. To describe the whole picture, as the first step, it was aimed to determine what Turkish academics and graduate students need in terms of foreign language academic literacy competencies, namely academic reading, writing and listening. As a result of this need analysis study it was intended to suggest solutions to overcome the occurring problems due to limited foreign language academic literacy and to improve the academics' language proficiency.

The rationale of need analysis is to reveal any potential gap between the individuals can do and what they are in fact required to be able to do (Ramani \& Pushpanatan, 2015). Particularly for English for Academic Purpose (EAP), to determine individuals' academic language proficiency, there is not any standardized assessment protocol accepted worldwide even national platforms. As Grigorenko (2015) stated academic language proficiency should be evaluated according to the demands of the context, tasks and language skills to use and even individual aptitudes and differences. Thus, to offer the most effective assessment tool and teaching opportunities for academic language proficiency, to determine the needs of target population within the specific contexts considering the certain demands is crucial. Addressing to this, the present study aimed to determine the academic language proficiency needs of Turkish academics, who use academic English in English as a Foreign Language (EFL) context and who use academic reading and writing skills for searching and publishing the articles more than listening and speaking in academic contexts. The academic language demands on Turkish academics are apparently different from other academics in different countries in which English is used as a second language (ESL). Thus, it can be claimed that to apply any assessment or teaching techniques designed specifically for the individuals with different language demands and contexts is not reliable. Therefore, the present study can be seen as the first step to describe the phenomenon of academic language in Turkey focusing on the target population and the needs. Additionally, the findings can contribute further studies to discuss the specific demands that lead to the needs and to offer any assessment tool and teaching-learning processes appropriate to these needs.

\section{Significance of Needs Analysis and Learners' Skill-Based Language Needs}

Needs analysis mainly emerged as a part of English for Specific Purposes (ESP) to deal with language learners' needs and to design language courses meeting learners' personal and social needs in the 1970s (Palacios, 1992). According to Graves and Xu (2000), needs analysis in language learning is the process of systematic and continuous collection of information about the students' needs and preferences, interpretation of the collected data and then decision-making to meet these needs. The language needs of adult language learners are observed in various social and educational areas where that language is widely used. Needs and motivation should not be confused, though 
(Richteric, 1972). Needs emerge from the reality of the areas where the language is used and knowing a language requires meeting various demands in this reality as needed. However, motivation relates to learners' attitudes or willingness when it comes to making effort to learn the language. In this regard, investigating the needs makes it possible to put forward effective goals, so the steps to be taken about a language and language learning can be determined.

The fundamental focus of needs analysis in education programs is on learners' needs about learning, and the needs identified turn into learning goals, which contributes to the development of teaching materials, activities, program evaluation criteria and exams. (Brown, 2009). According to a similar view, needs analysis in ESP defines necessary language abilities, texts, language forms and communicative activities for educators to prepare suitable teaching curriculum and materials for certain occupational, academic and professional realities (Hyland, 2007). Therefore, as mentioned in many studies, this awareness is transformed into reasonable content to be dealt with in language classes (Hutchinson and Waters, 1987; Palacios, 1992; Hyland, 2007; Brown, 2009).

Considering that EAP teaching is a branch of ESP, it has great complexity and variety with regard to the elements it involves. Carrying out an extensive needs analysis prior to any ESP teaching program or material development is vital (Johns, 1991). In brief, this complex structure constitutes leaners' learning disabilities and "gaps", levels of language, context and stakeholders (Cacumba, 2014). Thus, needs analysis, a process to collect information on all these elements, has great importance in developing programs and materials that are suitable for learners' needs, the contexts and the levels that they are expected to use language in (Cacumba, 2014). As Kumazawa (2006) indicates, welldefined goals in language programs, which can be determined with a comprehensive needs analysis, are crucial, and through these goals, it can be possible to detect to what extent learners achieve these goals and to evaluate the effectiveness of the programs and tools, and accordingly, to design the most appropriate assessment tools to measure learners' competencies.

As for specific academic literacy skills, reading is argued to be the most important one that learners should attain (Grabe \& Stoller, 2001), which is supported by many studies reporting a considerable amount of learners' and academicians' opinions that reveal the significance of reading skills for academic purposes (Rosenfeld, Leung, \& Oltman, 2001; Snow, Burns, \& Griffin, 1998). In the academic context, reading is the main tool to learn new information and reach alternative interpretations. In addition, reading skills contribute to synthesizing and developing critical evaluation skills.

When academic reading ability is considered, it is very important to conduct a needs analysis taking not only the characteristics and needs of the target group but also the requirements of the context concerned. Such a needs assessment was conducted by Park (2012) to investigate whether learning outcomes of a reading course for foreign students met the learners' needs in an academic context. Based on her learners' and academics' views, she reported that $72 \%$ of the students in different academic contexts considered reading articles in academic journals as the most important skill while $28 \%$ of them stated that reading lab instructions and reports is the most necessary skill. They reported 
to have difficulty in vocabulary specific to their fields, reading comprehension, dealing with long and complex texts, general academic vocabulary, using reading strategies and reading speed.

Writing, which is usually regarded as the second most important academic skill, is an essential part of EAP teaching and highly needed by leaders to fulfill their academic studies and pursue a successful career (Jackson, 2004; Choi, 2012; Aliakbari \& Boghayeri, 2014). In Chostelidou (2010)'s study in ESP, the writing needs reported by the participants in significant percentages were writing notes, memos, emails, formal or informal letters, and analyzing and reporting tables or graphics. In addition, developing arguments, connecting sentences and paragraphs, writing well-developed paragraphs, writing introductions and body paragraphs and organizing ideas were the areas in which the participants felt a need to practice. The learners reported they needed support in writing academic texts such as essays, reports, and dissertations (Akyel and Özek, 2010 and Tsou, 2009) as well as case studies, projects and master's theses (Tsou, 2009).

Listening is a very essential skill in language acquisition, and comprehending what has been listened is a rather complicated mental process (Chung, 2002). In academic contexts, the importance of listening skills in a foreign language is also undeniable. In this regard, a series of micro-skills for academic skills such as identifying the purpose and scope of a lecture, following the topic development in a lecture and identifying and inferring relationships among idea units were identified (Rahman, 2009). Needs analysis studies were carried out in various contexts including Malaysia (Rahman, 2009), Taiwan (Teng, 2000) and Australia (Dooey, 2006). In Rahman (2009), Malaysian graduate students listed listening to lectures, seminars, supervisors, and other students in group discussions as the most important academic listening tasks for them. In Feng (2001), Taiwanese university students had daily conversational needs rather than academic listening, and the most important listening competencies they needed were identifying keywords and following different types of lectures. On the other hand, in a native English-speaking context, Dooey (2006) reported instructors' and university students' views on listening needs, and found that note-taking, general listening and listening to daily conversations were the most prominent listening competencies from their perspectives.

In 2013 and 2015, an extensive needs analysis was carried out throughout Turkey by British Council and TEPAV (the Economic Research Policy Foundation of Turkey) to investigate existing problems and how English teaching could be improved in the Turkish context. By means of this need analysis including learners, teachers and parents; suggestions for future implications were made, referring to basic English language teaching. As mentioned in this report, analyzing target populations' needs is important in determining contextual differences and learners' features before suggesting implications for large masses. While the British Council-TEPAV (2015) reports focused on general English teaching, the present study focuses on academic English literacy needs that also concern large masses across Turkey and have not been dealt with in a detailed way before in the Turkish context. 


\begin{abstract}
Aims and Research Questions
The primary aim of this study was to determine and discuss which language skill is the most difficult for Turkish graduate students and academics, and what language skill competencies they should improve from their own perspective. The following research questions were addressed in the study:
\end{abstract}

(i) Which academic language skill was perceived as the most difficult by Turkish academics and graduate students?

(ii) What specific language skill competencies did Turkish academics and graduate students need the most in their academic endeavors?

(iii) Were there any differences in Turkish academics' and graduate students' academic literacy needs in terms of academic title and discipline?

Through these research questions, the present study aimed to conduct a large-scaled need analysis on academic English proficiency of Turkish academics and graduates. Although the significance of need analysis has been emphasized in literature (Berman \& Cheng, 2010; Kaur \& Khan, 2010) and it has been put forth that need analysis is the best way to involve learners in the process (Richards, 2001), there is no comprehensive need analysis study on academic English proficiency of academics in Turkey. Thus, this study intended to address this gap and make academics' voices heard as to contribute to the studies on the solutions about how to improve their limited academic English proficiency.

This study covers the needs related to three main academic language skills as reading, writing and listening. The speaking skill was not included within the content. The main reason is the nature of speaking skills as much more complex to document and measure as a language skill. Furthermore, in a foreign language context like Turkey, academics and graduate students can be said to need academic reading, writing and listening to succeed in their career more than they do for speaking. Surely, they do need to speak in their conference presentations, but such speeches do not go beyond merely reading what they wrote beforehand. Therefore, due to the complexity of the speaking skill and the characteristics of the Turkish context, this study only focused on academic reading, writing and listening skills. In further studies, the speaking skill will be focused.

\title{
METHOD
}

\section{Research Design}

Within the framework of quantitative research method, the research design of the present study is survey model to describe the current situation. Descriptive studies aim at researching a case as it is and determining the existing case. The survey model, which is commonly used in descriptive studies, is a research model that aims to determine the formations of variables in terms of type or amount, or the existence or degree of change between two or more variables (Karasar, 2005). Since the present study aimed to describe an existing situation (academics' foreign language academic literacy needs), it was designed by adopting a cross-sectional survey model (Büyüköztürk et al., 2012; Karasar, 2005; Mertens, 2014). 


\section{Participants}

The population of the study consisted of Turkish academics and graduate students who work in different disciplines (i.e. grouped as hard sciences, social sciences, educational sciences and English language teaching). English language teaching, or ELT, academics and students were also included because they can be considered as language education professionals, which can make them more conscious about specific language needs in the Turkish context.

Random sampling was adopted in this study to select the research sample. In simple random sampling, each individual within the population is given a chance to be included in the sample (Büyüköztürk et al., 2012). Accordingly, the scale used in the study was sent to academics and students in different universities located in all seven geographic regions across Turkey. Out of around 5,000 individuals who received the scale, 2,198 academics and students filled the scale voluntarily. The distributions of the participants based on geographical region, academic title and discipline are presented in Table 1.

Table 1

Distribution of the participants' region, title and discipline

\begin{tabular}{llllll}
\hline Geographical Region & $N$ & Academic Title & $n$ & Discipline & $n$ \\
\hline Mediterranean & 253 & Prof. Dr. & 195 & ELT & 375 \\
Eastern Anatolia & 124 & Assoc. Dr. & 240 & Education & 394 \\
Aegean & 164 & Assist. Prof. Dr. & 589 & Social & 590 \\
Southeast & 50 & Lecturer & 79 & Hard & 839 \\
Central Anatolia & 827 & Research Assist. & 773 & & \\
Marmara & 440 & Instructor & 322 & & \\
Black Sea & 340 & & & & 2198 \\
Total & 2198 & Total & 2198 & Total & \\
\hline
\end{tabular}

As presented in Table 1, most of the participants were from universities located in the central Anatolia region $(n=827)$. As for academic title, almost one-third of the participants were research assistants doing their $\mathrm{MA}$ or $\mathrm{PhD}$ at the time of the study, followed by assistant professors $(n=589)$ and instructors $(n=322)$. Regarding disciplines, more than one-third of the participants were from hard sciences, followed by those working in social sciences $(n=590)$, educational sciences $(n=394)$ and ELT $(n=375)$.

\section{Data Collection Instrument}

To determine the participants' needs of foreign language academic literacy, a scale was developed through a Delphi study, in which experts from different academic fields participated in the discussion on foreign language academic literacy competencies of Turkish scholars. After two Delphi rounds and comprehensible consensus analyses, 67 items were finalized. Out of the 67 items, 28 were related to individuals' academic reading, 24 academic writing and 15 academic listening needs.

The first version of the scale was piloted through an online tool, Survey Monkey (https://tr.surveymonkey.com/r/tracademicliteracy). The participants of the pilot study consisted of 300 academics. Explanatory factor analysis, reliability and validity studies were conducted on the findings of pilot study. The results of the analyses indicated that 
the foreign language academic literacy needs analysis scale consisted of three factors, covering each language skill (i.e. Academic Reading; Academic Listening and Academic Writing) with a total of 64 items with overall 0.98 Cronbach value.

The items were rated on 5-point Likert scale ranging from (5) "I need it the most" to (1) "I don't need it at all".

The final version of the scale was administered by means of the same online tool. It was sent to academics with different academic titles and working at the different universities located across different regions of Turkey. The participants were invited via e-mail, and remainders were sent twice during the data collection period. In total, 2198 academics with different academic titles from universities in the seven regions of Turkey participated in the study.

\section{Data Analysis}

Descriptive analysis, such as the mean score standard deviation, Q1, median and Q2 was used to interpret the data on the distribution of participants' responses. To investigate whether the differences among groups and variables are significant or not one-way ANOVA and Welch test were applied. In case of unequal variances, Welch test was used on the other hand, one-way ANOVA was applied with normal, equal distributions. The statistical significance of the data reported in this paper is set at the level of $p>0.05$. Then post hoc test was conducted to determine the group that caused the difference.

\section{FINDINGS}

The collected data were analysed through descriptive and inferential statistics in order to determine the participants' foreign language academic literacy in terms of three basic language skills. The obtained results are given in Table 2.

Table 2

Descriptive Statistics Obtained from the Need Analysis Scale

\begin{tabular}{llll}
\hline & $\mathrm{n}$ & Mean & SD \\
\hline Academic Reading & 2198 & 4.14 & .89439 \\
Academic Writing & 2198 & 4.28 & .82035 \\
Academic Listening & 2198 & 4.12 & .88915 \\
Total & 2198 & 4.19 & .80237 \\
\hline
\end{tabular}

The results showed that the mean of participants' needs is high $(\bar{X}=4.19)$ in overall, which indicated that the participants needed most of the academic language literacy competencies questioned in the scale. In other words, the Turkish academics participated in the study reported that they did not have sufficient academic language literacy competencies and they needed to improve their competence in most of them.

When the participants' answers were analyzed in terms of each language skill, it was seen that the participants mostly needed academic writing competencies $(\bar{X}=4.28)$. It was followed by the needs for academic reading and listening competencies. The distribution is illustrated in Figure 1. 


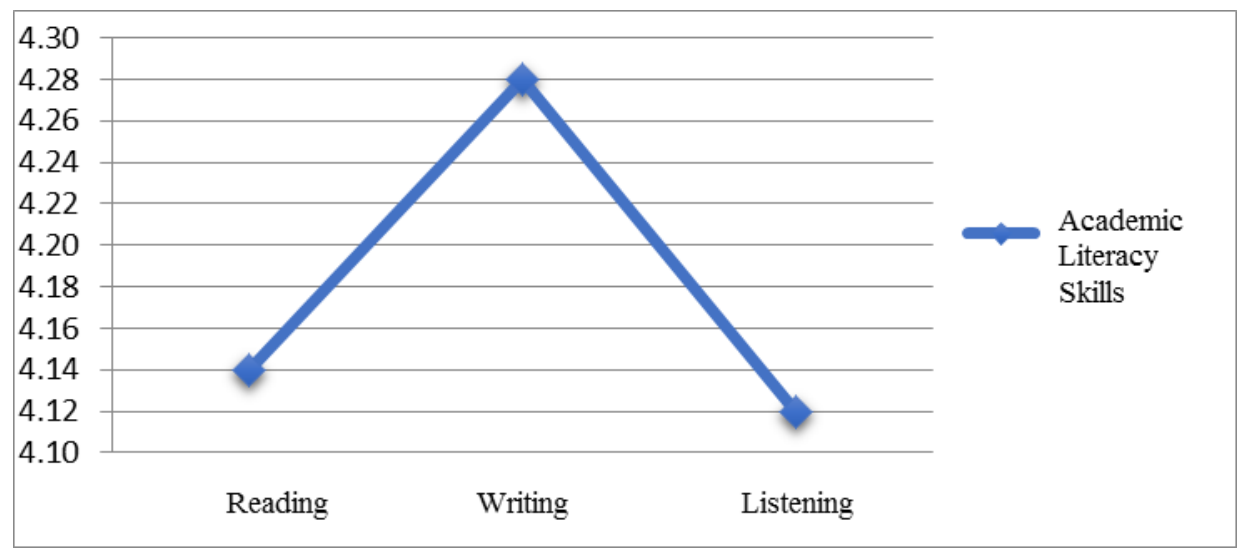

Figure 1

Distribution of the Participants' Needs for Academic Language Skills

As seen in Figure 1, the participants' need for academic writing competencies had the highest mean among the three skills focused in the present study. This finding is consistent with other studies in literature, which agree that writing is the most difficult skill for language learners and they need to improve many writing competencies before having the mastery of the target language. The academic writing needs most frequently stated by the participants are given in Table 3 .

Table 3

The Most Frequent Academic Writing Needs

\begin{tabular}{|c|c|c|c|c|c|c|}
\hline & Academic Writing & Mean & SD & Q1 & Median & Q3 \\
\hline 27 & $\begin{array}{l}\text { To be able to write clear thesis statements that } \\
\text { correspond the intended message to be delivered }\end{array}$ & 4.38 & .905 & 4.00 & 5.00 & 5.00 \\
\hline 46 & To be able to use proper academic language & 4.36 & .948 & 4.00 & 5.00 & 5.00 \\
\hline 31 & $\begin{array}{l}\text { To be able to put forward a clear and understandable } \\
\text { claim }\end{array}$ & 4.34 & .922 & 4.00 & 5.00 & 5.00 \\
\hline 34 & $\begin{array}{l}\text { To be able to write a conclusion paragraph } \\
\text { supporting the paper in general }\end{array}$ & 4.34 & .971 & 4.00 & 5.00 & 5.00 \\
\hline 26 & $\begin{array}{l}\text { To be able to generate ideas to write by using } \\
\text { different sources }\end{array}$ & 4.32 & .915 & 4.00 & 5.00 & 5.00 \\
\hline 41 & $\begin{array}{l}\text { To be able to write coherent and consistent } \\
\text { explanations }\end{array}$ & 4.32 & .964 & 4.00 & 5.00 & 5.00 \\
\hline 35 & $\begin{array}{l}\text { To be able to reflect how similar topics and themes } \\
\text { are dealt in different sources to the paper s/he writes }\end{array}$ & 4.31 & .930 & 4.00 & 5.00 & 5.00 \\
\hline 39 & To be able choose and use appropriate vocabulary & 4.31 & .933 & 4.00 & 5.00 & 5.00 \\
\hline 33 & $\begin{array}{l}\text { To be able to avoid from plagiarism while using } \\
\text { different sources }\end{array}$ & 4.30 & 1.007 & 4.00 & 5.00 & 5.00 \\
\hline 43 & $\begin{array}{l}\text { To be able to form a reasonable flow of ideas and } \\
\text { events in the text s/he writes and to be able to make } \\
\text { connections among them }\end{array}$ & 4.30 & .945 & 4.00 & 5.00 & 5.00 \\
\hline
\end{tabular}

International Journal of Instruction, January2019 • Vol.12, No.1 
The participants stated that they needed the most was to be able to write clear thesis statements that correspond the intended message to be delivered ( $\bar{X}=4.38, \mathrm{SD}=.905)$.

This competency was followed by being able to use proper academic language ( $\bar{X}=4.36$,

$\mathrm{SD}=.948)$, being able to put forward a clear and understandable claim $(\bar{X}=4.34$, $\mathrm{SD}=.922$ ) and being able to write a conclusion paragraph supporting the paper in

general ( $\bar{X}=4.34, \mathrm{SD}=.971$ ). When other frequent academic writing needs were examined, it was seen that they were related to other parts of the academic writing process. Such needs include being able to write a clear topic sentence by also using different sources, being able to choose appropriate vocabulary, being able to use academic language, and being able to form a flow of events. The needs analysis scale revealed that the second most needed skill for the participants was academic reading. Table 4 shows the most frequently needed academic reading competencies.

Table 4

The Most Frequent Academic Reading Needs

\begin{tabular}{|c|c|c|c|c|c|c|}
\hline & Academic Reading & Mean & SD & Q1 & Median & Q3 \\
\hline 1 & $\begin{array}{l}\text { To be able to read different text genres such as news, } \\
\text { course books, articles, research papers including } \\
\text { internet sources }\end{array}$ & 4.41 & .961 & 4.00 & 5.00 & 5.00 \\
\hline 2 & $\begin{array}{l}\text { To be able to analyze information and discussions } \\
\text { presented in the text }\end{array}$ & 4.32 & .975 & 4.00 & 5.00 & 5.00 \\
\hline 6 & $\begin{array}{l}\text { To be able to skim the relevant articles and books and } \\
\text { to be able to decide whether they are useful }\end{array}$ & 4.32 & 1.044 & 4.00 & 5.00 & 5.00 \\
\hline 7 & $\begin{array}{l}\text { To be able to comprehend texts including common } \\
\text { terminology and expressions of his/her field }\end{array}$ & 4.29 & 1.108 & 4.00 & 5.00 & 5.00 \\
\hline 3 & To be able to make logical assumptions from the text & 4.26 & .988 & 4.00 & 5.00 & 5.00 \\
\hline 5 & To be able to reach a conclusion from a text & 4.23 & 1.019 & 4.00 & 5.00 & 5.00 \\
\hline 8 & To be able to get the gist of a text & 4.21 & 1.097 & 4.00 & 5.00 & 5.00 \\
\hline 10 & $\begin{array}{l}\text { To be able to determine the gist and supporting ideas } \\
\text { in a text }\end{array}$ & 4.17 & 1.048 & 4.00 & 4.00 & 5.00 \\
\hline 11 & $\begin{array}{l}\text { To be able to interpret the vocabulary and expressions } \\
\text { of a text and to be able to distinguish any differences } \\
\text { regarding their meaning }\end{array}$ & 4.17 & 1.014 & 4.00 & 4.00 & 5.00 \\
\hline 22 & $\begin{array}{l}\text { To be able to opine about the relevant field by } \\
\text { comprehending the main ideas presented in a text }\end{array}$ & 4.17 & 1.029 & 4.00 & 4.00 & 5.00 \\
\hline
\end{tabular}

When the needs of academic reading were considered, the academics mostly needed reading different text genres such as news, course books, articles, research papers including internet sources $(\bar{X}=4.41, \mathrm{SD}=.961)$. This was followed by being able to analyze information and discussions presented in a text $(\bar{X}=4.32, \mathrm{SD}=.975)$ and being able to skim the relevant articles and books and being able to decide whether they are useful $(\bar{X}=4.32, \mathrm{SD}=1.044)$ consecutively. Lastly, in Table 4, the most frequent needs 
related to academic listening, which is the least needed academic skill according to the needs analysis scale, are presented.

Table 4

The Most Frequent Academic Listening Needs

\begin{tabular}{|c|c|c|c|c|c|c|}
\hline & Academic Listening & Mean & SD & Q1 & Median & Q3 \\
\hline $\begin{array}{l}5 \\
0\end{array}$ & $\begin{array}{l}\text { To be able to comprehend the important terminology } \\
\text { and vocabulary related to the field/topic }\end{array}$ & 4.21 & 1.029 & 4.00 & 5.00 & 5.00 \\
\hline $\begin{array}{l}5 \\
2\end{array}$ & $\begin{array}{l}\text { To be able to understand the main idea and } \\
\text { supporting ideas while listening }\end{array}$ & 4.20 & .981 & 4.00 & 4.00 & 5.00 \\
\hline $\begin{array}{l}5 \\
3\end{array}$ & $\begin{array}{l}\text { To be able to make deductions by referring to the } \\
\text { information s/he has listened to }\end{array}$ & 4.20 & .990 & 4.00 & 4.00 & 5.00 \\
\hline $\begin{array}{l}5 \\
8\end{array}$ & $\begin{array}{l}\text { To be able to listen to and understand the } \\
\text { information presented in the media, online } \\
\text { conferences and seminars }\end{array}$ & 4.20 & 1.002 & 4.00 & 4.00 & 5.00 \\
\hline $\begin{array}{l}5 \\
7\end{array}$ & $\begin{array}{l}\text { To be able to recognize the supporting ideas or the } \\
\text { ideas that contradict or confute with the main idea/s }\end{array}$ & 4.19 & .990 & 4.00 & 4.00 & 5.00 \\
\hline $\begin{array}{l}5 \\
4\end{array}$ & $\begin{array}{l}\text { To be able to understand the phases of the speeches, } \\
\text { lectures or courses (introduction, revision of the } \\
\text { previous knowledge, presentation of the new } \\
\text { information, summary and conclusion) }\end{array}$ & 4.18 & 1.026 & 4.00 & 4.00 & 5.00 \\
\hline $\begin{array}{l}5 \\
1\end{array}$ & $\begin{array}{l}\text { To be able to use his/her background knowledge to } \\
\text { understand unknown terminology or the context }\end{array}$ & 4.16 & .971 & 4.00 & 4.00 & 5.00 \\
\hline $\begin{array}{l}6 \\
2\end{array}$ & $\begin{array}{l}\text { To be able to realize the transitions that show the } \\
\text { relations among the themes } \mathrm{s} / \mathrm{he} \text { is listening to }\end{array}$ & 4.12 & 1.012 & 4.00 & 4.00 & 5.00 \\
\hline $\begin{array}{l}6 \\
0\end{array}$ & $\begin{array}{l}\text { To be able to make connections between his/her } \\
\text { background knowledge and the new information } \\
\text { presented by the speaker }\end{array}$ & 4.11 & 1.036 & 4.00 & 4.00 & 5.00 \\
\hline $\begin{array}{l}5 \\
6\end{array}$ & To be able to take notes while listening & 4.10 & 1.036 & 4.00 & 4.00 & 5.00 \\
\hline
\end{tabular}

The most needed academic listening competency was being able to comprehend the

important terminology and vocabulary related to the field/topic $(\bar{X}=4.21, \mathrm{SD}=1.029)$. This competency was followed by being able to understand the main idea and supporting ideas while listening $(\bar{X}=4.20, \mathrm{SD}=.981)$, being able to make deductions by referring to the information s/he has listened to $(\bar{X}=4.20, \mathrm{SD}=.990)$ and being able to listen to and understand the information presented in the media, online conferences and

seminars $(\bar{X}=4.20, \mathrm{SD}=1.002)$.

The reason why the participants' need academic listening skills less than the other two can be explained by the fact that they did not use these skills as much as the other two. In other words, the participants' need academic listening skills less. It is known that the academicians participated in the study use academic reading skills most as they are supposed to read the literature of their field. Therefore, their academic reading needs have focused on the skills that can help them improve their literature review. On the other hand, academic writing skills, that the participants need most, have become 
prominent as the participants need to improve in order to publish and share their studies internationally.

When the results of the survey were analyzed in terms of the academic titles, it was seen that the research assistants participated in this study reported the highest need for the three academic literacy skills, and they stated that they needed academic writing competencies the most $(\bar{X}=4.37, \mathrm{SD}=.753)$, which is followed by academic reading $(\bar{X}=4.26, \mathrm{SD}=.836)$ and listening competencies $(\bar{X}=4.21, \mathrm{SD}=.823)$. On the other hand, the group with the lowest need for the academic literacy skills was professors. They also needed academic writing competencies the most $(\bar{X}=4.12, \mathrm{SD}=.908)$, which is followed by reading $(\bar{X}=3.98, \mathrm{SD}=.982)$ and listening competencies $(\bar{X}=3.98, \mathrm{SD}=.944)$. The distribution of the academic literacy skill needs is presented in Figure 2.

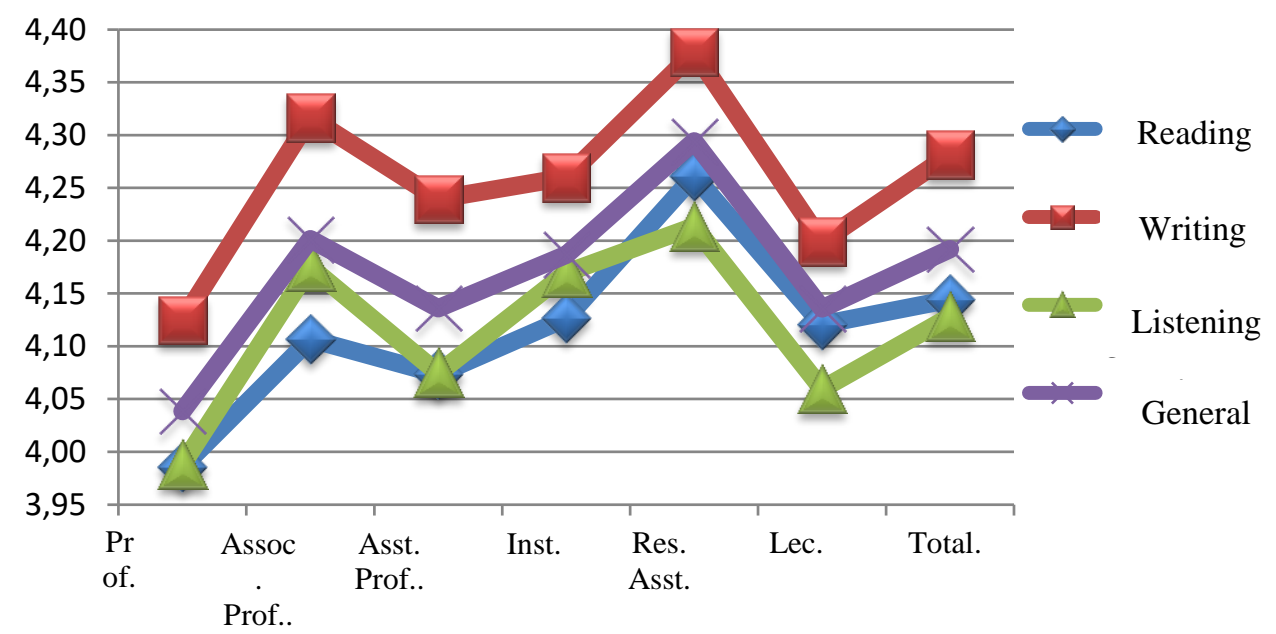

Figure 2

Distribution of the Participants' Needs Based on Academic Title

In overall, research assistants and associate professors had higher needs in three academic literacy skills than those with other titles. In other words, the participants in these titles reported to need the academic literacy competencies included in the scale more than the others. Furthermore, the professors stated to need these competencies at a lower level compared to the participants with other titles. The results of the Welch test revealed significant differences between academic titles in reading $(F(5,496.218)=4.747, \quad p<.001), \quad$ writing $\quad(F(5,493.641)=4.897, \quad p<.01), \quad$ listening competencies $\quad(F(5,497.659)=3.471, \quad p<.001), \quad$ and in the whole scale $(F(5,494.686)=4.990, p<.001)$. In order to determine the source of these significant 
differences, the Games-Howel post-hoc test was performed. The results showed that there were significant differences between professors and research assistants in academic reading, writing and listening, and between assistant professors and research assistants in academic reading and writing. These differences were in favor of the research assistants.

As the third phase of the study, Turkish academics' needs on academic language competencies were examined in terms of the disciplines that participants studied. Regarding the disciplinary differences, the highest need was reported by the academics in hard sciences $(\bar{X}=4.21, \mathrm{SD}=.802)$ followed by those in social sciences $(\bar{X}=4.19$,

$\mathrm{SD}=.794)$, educational sciences $(\overline{\bar{X}}=4.17, \mathrm{SD}=.866)$, and lastly ELT $(\overline{\mathcal{X}}=4.16, \mathrm{SD}=.761)$. The distribution of the academic literacy skill needs in terms of disciplines is presented in Figure 3 .

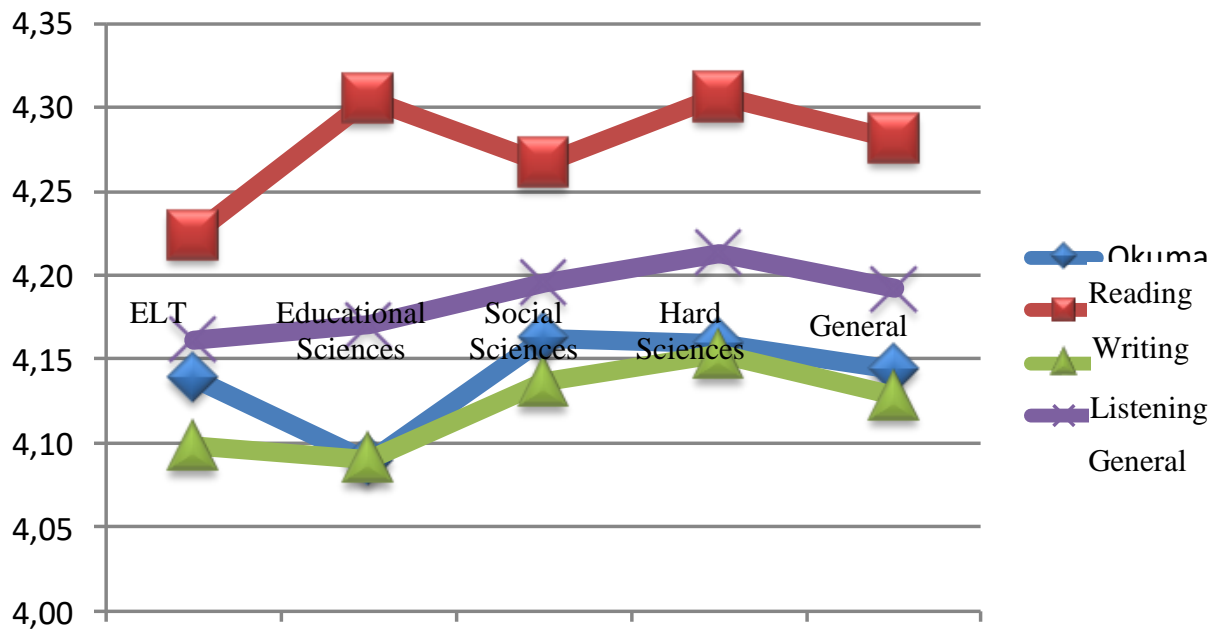

Figure 3

Distribution of the Participants' Needs Based on Disciplines

As the results indicated while the academics in ELT had the lowest need in academic literacy competencies except academic writing, it was the participants in educational sciences who had the lowest need in academic writing competencies. Moreover, the participants in hard sciences had a higher need in academic literacy competencies except academic reading compared to those in other disciplines, while the participants in social sciences had the highest need in academic reading competencies. The results of ANOVA and the Welch test did not reveal any statistically significant differences between the participants in terms of disciplines in academic reading 
$(F(3,1019.367)=.573, \quad p>.05), \quad$ writing $\quad(F(3,2194)=1.050, \quad p>.05), \quad$ listening $(F(3,1004.275)=.592, p>.05)$, and general academic literacy $(F(3,2194)=.476, p>.05)$.

To sum up, the findings of the study indicated that Turkish academics need to improve academic language literacy competencies for certain skills, particularly for academic writing, thus the findings revealed that the needs are skill specific. When the needs were examined in terms of each competency of the skills, it was seen that the participants reported certain competencies as more necessary to improve. These competencies compose the basic dynamics of the skills such as writing thesis statement for academic writing; reading different genres and comprehending the terminology while listening. To make sense of Turkish academics' needs better, different academic titles and disciplines of the academics were taken into investigation. The results indicated observables differences in the mean values among the participants for both academic titles and disciplines, yet the differences were only statistically meaningful in terms of academic titles. These results will be discussed referring to the dynamics of Turkish context and related literature in the following.

\section{DISCUSSION}

Although the significance of academic language literacy has been emphasized in literature recently (Chimbganda, 2011; Savaş, 2009) and Turkish academics' difficulties in academic language literacy have been reported so far (YÖK, 2014), there is a lack of study on the foreign language academic literacy of Turkish academics. Addressing to this neglected area, the present study conducted a need analysis on Turkish academics' needs of foreign language academic competencies. As the rationale underlying the need analysis is to reveal the gap between what the target population need and what is done and the needs are shaped according to the demands of the context, individual differences; the present study firstly aimed to shed light on Turkish academics who have different and specific concerns, context dynamics, purposes to use academic language. In that way, the results of the present study can provide an empirical data so teaching and assessment implication, which are specific and appropriate to Turkish academics can be offered in further studies and projects.

To achieve this outcome, the present study conducted a need analysis according to survey model with a large-scaled population, 2,198 academics with different academic titles and different disciplines in Turkey. The participants' needs on three main language skills; reading, listening and writing and competencies for each skill in academic context were investigated. Mainly, the aim of the present study is to to determine and discuss which language skill is the most difficult for Turkish academics in terms of academic titles and disciplines as well, and what language skill competencies they should improve from their own perspective. Addressing to this aim three research questions were asked.

For the first research question, which inquired the most difficult skill perceived by Turkish academics, the results indicated that the academics reported that they needed academic writing competencies the most, followed by academic reading and listening competencies, respectively. This result complies with the literature as it is widely accepted that writing is the most difficult skill for many non-native individuals (Grabe \& 
Kaplan, 1996). Therefore, the non-native leaners need more support to overcome the difficulties they encounter while producing, writing in English (Berman \& Cheng, 2011). From another point of view, the participants' emphasis on their difficulties and needs particularly for academic writing can be considered to indicate that they accept writing as an essential skill to develop and they are more aware of their needs for this skill. In fact, this assumption is also widely accepted in many studies in literature (Edwards, 2000; Kaur \& Clarke 2009; Salehi, 2010; Baghban, Naeini \& Pandian, 2013; Spence \& Liu, 2013).

Like the present study, some studies also reported the undergraduate and graduate participants' similar difficulties and emphasized their needs particularly for academic writing in English (Chimbganda, 2011; Berman \& Cheng, 2011). The reason for these results, it was put forth that writing is a productive skill encompassing all language skills. For academic writing, individuals need to master grammar and vocabulary as well as analysing, synthesizing and referring to what they read and listen (Grabe \& Kaplan, 1996). This assumption was also supported with the results on the participants' needs for the competencies under academic language skills under focus.

According to the results on the specific competencies that the participants reported to need, which was questioned under the second research question of the study, the most needed academic writing competency was being able to write clear thesis statements that correspond the intended message to be delivered. Being able to use proper academic language, put forward a clear and understandable claim and write a conclusion were among other writing competencies in which the Turkish academics highly needed according to their responses. These competencies were also discussed in similar studies in literature (Berman \& Cheng, 2010; Akyel \& Özbek, 2010). Chostelidou's (2010) findings supported these results and agreed that writing clear thesis statement is one of the biggest challenges that many non-native students encounter.

For academic reading, which was revealed as the second skill that the participants needed to improve, the participants reported relatively high needs. Particularly the competency of being able to read different text genres such as news, course books, articles, research papers including internet sources was agreed by the most participants to develop. Wahyono and Puspitasari (2015) shared the similar results that the graduate and post graduate students had difficulties in reading different reading genres and this could hinder their comprehension; correspondingly their writing performance. This result could also explain why the participants of the present study reported higher level of needs for academic writing as well.

Although listening was obtained as the least frequent skill needed to develop according to the participants, this result in fact implied that the participants need to gain awareness about this necessity of this skill. As Flowerdew and Miller (2005) state, the neglect of listening in foreign language teaching practices may have led to the Turkish academics' reporting a low level of need in this skill. It can be said that since they do not use this skill so frequently they are not aware of their needs on this skill. 
The results on the specific competencies that the academics reported to need indicated that the participants consciously evaluated their needs. In other words, they were aware of their deficiencies in terms of skills. When the most frequent competencies for each skill were examined, it could be seen that they are the basic dynamics of each skill. The participants chose the certain competencies that hindered their proficiency in that skill. So these results can guide what to do to improve the participants' literacy. For instance, although Turkish academics could write in academic English, they were aware that their academic writing literacy was not qualified enough because they needed to improve their competency in writing thesis statement. Thus, remedial teaching implications could be suggested for these needs.

Different from the studies in literature, to get the meaning of these reported needs, the present study examined them in terms of two important variables, academic titles and disciplines the participants study. These variables were considered as important that shape the needs. As Grigorenko (2015) pointed out particularly for academic language, the context, tasks and purpose to use academic language are important to determine the needs.

The results of the present study also showed that Turkish academics' needs of academic language literacy competencies differed in terms of academic titles. While research assistants and associate professor reported to need the competencies more than professors. This result can be explained by academic promotion criteria and the frequency of using foreign language academic literacy skills. This is because research assistants more frequently use their academic literacy skills for reviewing the literature and writing in their assignments, reports and theses/dissertations during their graduate students, and they also gain academic promotion through their international publications. Therefore, professors who have reached the top of their career in terms of promotion would not probably need much their foreign language academic literacy skills. Considering the fact that the research assistant and associate professor use academic English more for searching and publishing as the requirement for their academic promotion in Turkey, the statistical significant difference in the needs of Turkish academics implied that the participant became more aware of their needs as they needed to use these skills. The more they need to use the more aware of the needs they become. The interrelationship between the awareness of the needs and the frequency was also confirmed with the need analysis in literature (Aliakbari, \& Boghayeri, 2014; Ramani, \& Pushpanathan, 2015).

When the disciplines that the participants studied and became expert were examined the differences in the mean values were examined. the academics in hard sciences reported the highest need in academic literacy skills, and they are followed by those in social sciences, educational sciences and ELT, respectively. These results complied with Grigorenko's (2015) assumption that academic language proficiency depends on the demands of the context and tasks to use it for. These results could constitute a base to suggest academic language courses specific for disciplines and needs, as appropriate to EAP approach. 
In a nutshell, the results on the participants' needs for these three academic language skills in terms of two variables indicated that the systematic need analysis is of great significance to increase the awareness and urge individuals to think on and develop. This mission and contribution of need analysis studies, particularly on academic language skills were also emphasized in literature (Berman \& Cheng, 2010; Chostelidou, 2010; Aliakbari, \& Boghayeri, 2014; British Council \& TEPAV, 2015). The results was hoped to contribute to literature and call for further studies on what to suggest to improve Turkish academics' needs on academic language literacy. In addition, as the results indicated that needs could change in terms of different variables, the further studies on the needs from different perspectives supported with qualitative data that could explain the reasons of some needs from the participants' views could be invaluable for literature as well. Lastly, on the bases of the results of these study, Turkish academics' ideas on how to recover these needs, deficiencies could be examined to suggest more realistic and to the point solutions.

\section{CONCLUSION}

The overall results of the study indicated that the participants needed most of the competencies questioned in the survey, and their needs were language-skill specific rather than discipline-specific. The participants mostly emphasized their needs for academic writing competencies while they also detected certain competencies for academic reading and listening. The results revealed that the systematic need analysis is essential to examine the participants' awareness and interrelated nature of language skills regardless their academic titles but regarding the requirements.

The findings obtained in this study can be used in various dimensions of EAP teaching in Turkey. Turkish academics have many needs in terms of academic English skills, and increasing and improving the education and trainings in this area is of great importance for international academic achievements in Turkey. The competencies reported to be needed by Turkish academics the most in this study should be considered in developing EAP curricula towards academics, implementing trainings and creating and administering academic English literacy tests in the Turkish context. Further studies can focus on qualitative data to examine Turkish academics foreign language academic literacy needs so as to gain richer data and report individual needs of academics in their own words that may not be yielded through a large-scale quantitative study.

\section{REFERENCES}

Akyel, A. S., \& Ozek, Y. (2010). A language needs analysis research at an English medium university in Turkey. Procedia-Social and Behavioral Sciences, 2(2), 969-

Aliakbari, M., \& Boghayeri, M. (2014). A needs analysis approach to ESP design in Iranian Context. Procedia-Social and Behavioral Sciences, 98, 175-181.

Baghban, Z. Z. V., Naeini, M. B., \& Pandian, A. (2013) A needs analysis approach: Is the reading skill prominent? Proceeding Asian Literacy Conference.16. 
Berman, R. \& Cheng, L. (2010). English academic skills: Perceived difficulties by undergraduate and graduate students, and their academic achievements. RCLA. CJAL, 4(1-2), 25-40.

British Council \& TEPAV (2013). Türkiye'deki Devlet Okullarında İngilizce Dilinin Öğretimine İlişkin Ulusal İhtiyaç Analizi. Ankara: Yorum Yayın.

British Council \& TEPAV (2015). Türkiye'de Yükseköğretim Kurumlarında İngilizce Bir Durum Analizi. Ankara: Yorum Yayın.

Brown, D. J. (2009). Foreign and second language needs analysis. Michael H.Long \& Catherine J. Doughty (Ed.). The Handbook of Language Teaching içinde (pp. 269293). Wiley-Blackwell: Blackwell Publishing Ltd.

Buckingham, J. (2008). Development of English academic writing competence by Turkish scholars. International Journal of Doctoral Studies. 3(8), 1-18.

Buyukozturk, S., Cakmak, E., Akgun, O., Karadeniz, S. ve Demirel, F. (2012). Bilimsel Arastırma Yontemleri. (12. Baskı). Ankara: Pegem Akademi.

Cacumba, J. S. C. (2014). Determining The academic reading needs of teacher trainees Of English At Isced-Huíla, Angola (unpublished master thesis). Southern Africa University / Applied Linguistics.

Chimbganda, B. A. (2011). Discovering academic literacy skills in English of first year ESL. International Journal of Linguistics, 3 (1),1-21.

Choi, J. (2012). Self-Access English learning needs: Student and teacher perspectives. Listening, 42(49), 15.

Chostelidou, D. (2010). A needs analysis approach to ESP syllabus design in Greek tertiary education: A descriptive account of students' needs. Procedia-Social and Behavioral Sciences, 2(2), 4507-4512.

Chung, J. M. (2002). The effects of using two advance organizers with video texts for the teaching of listening in English. Foreign Language Annals, 35(2), 231-241.

Dooey, P. (2006, February). Identifying the listening and speaking needs of international students in Experience of learning. Proceedings of the 15th Annual Teaching Learning Forum (pp. 1-2).

Edwards, N. (2000). Language for business: effective needs assessment, syllabus design and materials preparation in a practical ESP case study. English for Specific Purposes, 19, 291-296.

Feng, H. P. (2001). Writing an academic paper in English: An exploratory study of six Taiwanese graduate students (Doctoral dissertation, Teachers College, Columbia University).

Flowerdew, J., \& Miller, J. (2005). Second language listening. Theory and practice. Cambridge: Cambridge University Press. 
Genç, B. \& Bada, E. (2010). English as a World Language in academic writing. The Reading Matrix. 2 (10), 142-151.

Grabe, W. and Kaplan, R.B. (1996) Theory and practice of writing: An applied linguistic perspective. Longman, New York.

Grabe, W., \& Stoller, F. L. (2001). Reading for academic purposes: Guidelines for the ESL/EFL teacher. Teaching English as a second or foreign language, 3, 187-203.

Graves, K., \& Xu, S. (2000). Designing language courses: A guide for teachers. New York.

Grigorenko, M. (2015). A Brief introduction to academic language. Education Faculty Publications. 73.

http://digitalcommons.cedarville.edu/education_publications/73

Hutchinson, T., \& Waters, A. (1987). English for specific purposes: a Learningcentered approach. Cambridge: Cambridge University Press.

Hyland, K. (2007). Genre pedagogy: Language, literacy and L2 writing instruction. Journal of Second Language Writing, 16, 148-164, 10.1016, j.jslw.2007.07.07.005.

Hyland, K. (2009). Academic Discourse. London: Continuum.

Jackson, M. E., (2004). Will electronic journals eliminate the need for ILL?, Interlending \& Document Supply, 32(3), 192-193.

Johns, A. M. (1991). English for specific purposes (ESP): Its history and contributions. Marianne Celce-Murcia (Ed.), Teaching English as a second or foreign language içinde (pp. 67-77). Boston: Heinle \& Heinle.

Karasar, N. (2005). Bilimsel Araştırma Yöntemi. Onbeşinci Baskı. Ankara: Nobel Yayınları.

Kaur, S. and Clarke C. M. (2009). Analysing the English language needs of human resource staff in multinational companies. English for Specific Purposes, Issue 3 (24).

Kumazawa, T. (2006). Construct validation of a general English language needs analysis instrument. Shiken: JALT Testing \& Evaluation SIG Newsletter. 10 (2) 2-11.

Mertens, D. M. (2014). Research and evaluation in education and psychology: Integrating diversity with quantitative, qualitative, and mixed methods. Sage publications.

Palacios M. I. (1992). An Analysis and appraisal of the English language teaching situation in Spain from the perspectives of teachers and learners. (unpublished doctorate dissertation). Universidade de Santiago de Compostela.

Park, J. (2012). Needs Analysis of ELI 72 at UHM. Honolulu: Department of English as a Second Language, Manoa: University of Hawaii. 
Rahman, M. (2009). Academics' perceptions of reading and listening needs for English for Specific Purposes: A Case from national University of Malaysia. Language in India, 9(4), 292-311.

Ramani, N. \& Pushpanathan, T. (2015) Importance of needs analysis in ELT curriculum. International Journal of Advanced Multidisciplinary Research (IJAMR). 2(10), 98-100.

Read, J. (2008). Identifying academic language needs through diagnostic assessment. Journal of English for Academic Purposes, 7(3), 180-190.

Richard, J C., Platt, J., and Platt, H. (1992). Longman Dictionary of Language Teaching \& Applied Linguistics: Longman Group UK Limited.

Richards, J. (2001). Curriculum development in language teaching. Cambridge: Cambridge University Press.

Richterich, R. (1972). A Model for the Definition of Language Needs of Adults Learning a Modern Language. Strasbourg, France: Council of Europe.

Rosenfeld, M., Leung, S., \& Oltman, P. (2001). The reading, writing, speaking, and listening tasks important for academic success at the undergraduate and graduate levels. (TOEFL Monograph Series MS-21). Princeton, NJ: Educational Testing Service.

Salehi, M. (2010). Investigating the English language needs of engineering students. Retrieved April, 27, 2014.

Savaş, B. (2009). Role of Functional Academic Literacy in ESP Teaching: ESP Teacher Training in Turkey for Sustainable Development. Journal of International Social Research, 2(9), 395-406.

Snow, C., Burns, S., \& Griffin, P. (1998). Preventing reading difficulties in young children. Washington, D.C.: National Academy Press.

Spence, P., \& Liu, G. Z. (2013). Engineering English and the high-tech industry: A case study of an English needs analysis of process integration engineers at a semiconductor manufacturing company in Taiwan. English for Specific Purposes, 32(2), 97-109.

Teng, H. C. (2000). Analysis of EFL Listening needs by Taiwanese college students. Paper presented at the 9th Annual International Symposium on English Teaching, Taipei, Taiwan.

Tsou, W. (2009). Needs-based curriculum development: A case study of NCKU's ESP

Yagız, O. \& Yigiter, K. (2012). Academic writing difficulties and challenges in Advanced Academic Literacy. The Journal of Academic Social Science Studies. 5(8), 1261-1272.

YÖK (2014). Higher Education System in Turkey, Ankara: YÖK

Wahyono, E. \& Puspitasari, D. (2015). Students' need analysis of English reading skills for academic purposes. Proceeding of ICTTE, Vol. 1. No.1T: pp. 1007-1015 